\title{
Non-consumer based drivers of store success in a South African food retail group
}

\author{
M Vleggaar and EvdM Smit* \\ University of Stellenbosch Business School, \\ PO Box 610, Bellville 7535, Republic of South Africa \\ Eon.Smit@usb.ac.za and martinvl@telkomsal.net
}

\author{
Received September 2012
}

\begin{abstract}
The research objective of this study was to determine the key drivers of store success in a large food retail group in South Africa. The group currently operates in excess of 800 stores, managed by independent retailers on a franchise basis. Both the biographical details of the store owners and their management styles, demonstrate considerable variability. The effects of six categories of explanatory variables were related to two overall measures of store success sales growth and an internal measure of store performance - first pairwise and second, by stepwise multiple regression. The bibliographical profiles of the owners, with the exception of age and marketing experience did not predict store success, nor did the family history or number of stores owned. The legal form of ownership had no influence on performance either. As far as competition is concerned, specific competitors and competition density did not contribute to success, but the distance to the nearest competition was positively related to store performance.
\end{abstract}

The implementation of category management and an increased frequency of stock take, as examples of operational procedures, were positively associated with performance. Two leadership styles, one related to a clear articulation of values and the other to the management of deviations from set goals did positively impact on store performance. Active participation in the local community was also reflected in improved store performance.

Disappointingly, there was little evidence of significant relationships between retail sales growth and the selected variables. The multivariate model, however, explained approximately twenty per cent of the store performance measurements.

*To whom all correspondence should be addressed.

\section{Introduction}

The concept of voluntary trading, uniting the efforts of both the independent retailer and wholesaler, first took hold in the late 1920's in North America. It has been a long held belief that the independence of the store owners is one of their key strengths, and that the owner-based model transpires into a more effective and hands-on approach to managing a retail store. Most large supermarket groups, however, run on a corporate model, where a single entity owns all the retail stores and employs managers to run the daily aspects of the stores. The centralised model means that the parent body heavily influences the drivers of success at store level.

In a franchise model the success of the independent retailers and their stores is critical to the success of the group as a whole. Because of this, the group places emphasis on ensuring that the right calibre people buy their stores, and provides support to their retailers through a network of distribution centres. The group measures store performance on factors such as sales growth, adherence to various store standards, results from internal quality measures, market share growth and overall financial stability and profitability.
This study examined a sample selected from 685 store owners in South Africa, and attempted to correlate measures of store success with some traditional, and also some hypothesised, success drivers. The aim was to investigate what drives superior store performance in the group, and the role played by the store owner in achieving this success through a comprehensive analysis of the drivers of success in an independently owned supermarket. While, as pointed out Silvestro and Cross (2000), commonly held beliefs about successful stores may not always hold true, the fundamental business areas of marketing skills, organisational skills, logistical skills, management information system skills, accounting skills, and rank and file worker issues, as identified by Salmon (1989) sum up in broad terms the potential drivers of store success. The Service Profit Chain Framework identified by Heskett, Sasser and Schlesinger (1997) and further elaborated on by Stodnick (2005), identifies the importance of management practices, employee satisfaction and customer loyalty in driving store success. For the purpose of this study, the focus was placed on specific management practices and owner characteristics, with customer loyalty resulting from a well-run store. A key objective of this study was to develop insights into the contributions of owner characteristics, store 
characteristics and operational procedures, staff management practices, community involvement and different leadership styles in determining store success. This information may be valuable in selecting future franchise holders. The aim of the study, however, was not to test competing theories related to the different drivers of success.

Section 2 summarizes the current academic thinking on store success, Section 3 elaborates on the research process and data collection and Section 4 discusses the modelling and findings. Section 5 summarizes and concludes.

\section{Literature review}

\section{Key drivers of store success}

Cottrell (1973) proposed that environmental differences impacting on store performance should be taken into account when measuring performance across a group of stores and consequently evaluated the impact of the external environment on performance measures through considering factors such as social, demographic and economic parameters, and by studying the impact of competition in the surrounding area. He also considered the impact of the internal store environment on performance measures by analysing the impact of store price level, level of managerial activity and length of opening hours. Kumar and Karande (2000) extended the analysis by including explanatory variables such as increased service levels at the checkouts, 24 hour shopping facilities, double and triple couponing and the range of non-food items found in the grocery store. On a more integrated level, Reinartz and Kumar (1999) hypothesised that grocery store performance is influenced by four key variables: store characteristics, market potential characteristics, consumer characteristics and competition. They demonstrated that few studies integrate all these variables effectively, if at all and concluded that store location has the biggest influence on store performance, and that stores in densely populated areas outperform those in less urbanised environments. Stores pull customers disproportionally from people living in the immediate area.

Salmon (1989) focussed on the specific skill sets required by employees in retailing to allow for effective execution, which in turn would distinguish a winning company from a losing company. Marketing skills, organisational skills, logistical skills, management information system skills, accounting skills, and rank and file worker changes are identified as key factors required for retailing success. Earlier Hise, Gable, Kelly and McDonald (1983) reviewed eighteen variables to explain store performance. The variables were divided into four distinct sub-sections, namely store manager variables, store variables, competitive variables and location variables and were further classified as either controllable or uncontrollable, short run or long run, and reversible or irreversible.

Stodnick (2005) set out to identify the reasons for differences in store performance across various retail outlets in a women's specialty retail chain. The similarities between a specialty retail chain and grocery retail chain may not seem obvious at first. Both, however, are united by the vision of providing superior levels of customer service as a differentiating factor. The study used the Service Profit Chain framework to determine relationships between four interrelated variables, namely management actions (such as training), employee effects (such as satisfaction), customer findings (such as perceived quality and value) and market outcomes (such as sales growth and profitability). Both the framework used by Stodnick (2005) and the Service Profit Chain developed by Heskett et al. (2008) aim to develop relationships between store profitability and sales growth, customer loyalty, employee satisfaction, employee loyalty and overall productivity following Silvestro and Cross (2000) who had demonstrated correlations between profit and customer loyalty, customer satisfaction, service value, internal service value, output quality and productivity in a leading British supermarket chain. Hesket et al. (2008: 120) described the links in the Service Profit Chain as follows: "Profit and growth are stimulated primarily by customer loyalty. Loyalty is a direct result of customer satisfaction. Satisfaction is largely influenced by the value of services provided to customers. Satisfied, loyal, and productive employees create value. Employee satisfaction, in turn, results primarily from high quality support services and policies that enable employees to deliver results to customers". This research has emphasised the importance of satisfying employees to enable stores to satisfy customers. Hence Stodnick (2005) emphasises the importance of employee reward and incentive schemes, employee training programmes, levels of employee empowerment (ability to make own decisions), product availability and selection, product and service quality, store atmosphere and store layout.

Wellman (2007) described the Campioni brothers in Michigan as a successful family grocery business. The owners cited investments in store revamps and expansions, and a strong marketing campaign as factors that drive success across their five stores. They also stressed local knowledge and community involvement as major strengths for smaller independent store owners, and the ability to respond faster in reaction to changes in the local market places. Furthermore, having grown up in the grocery retail business from a very young age, they had learnt first-hand about every aspect of the grocery store. Wellman (2007) concluded that it was worthwhile to investigate the relationships between community involvement, the investments undertaken in store revamps and expansions, the marketing and advertising activities of the store, and the level of local knowledge of the storeowner in determining store success.

The current study focuses on some of the more intangible internal drivers of store success, and issues related directly to the ownership of a supermarket in South Africa. Therefore, based on discussions conducted with various executives and retailers, and by an assessment of the related literature, it has been decided to cluster the literature review into five areas, namely owner and business characteristics, store operational procedures, leadership styles, staff management and motivation and community involvement. However, it was felt necessary to control for some of the effects of the external environment, and hence a selection of competitor variables were included as part of the study. 


\section{Owner and business characteristics}

In most large organisations, care is taken to develop individuals into certain roles through training and development programmes, and by matching the background of the individual with the job requirements. This is not always the case with entrepreneurs, who often find themselves in industries and work situations requiring competencies in stark contrast with their previous experiences and knowledge. The differences in experiences and backgrounds of business owners have a bearing on business performance, and understanding which experiences contribute to the likely success of a business, is relevant to potential financiers, franchisors, and the business owners themselves. Specifically, this insight can guide the potential business owner into the correct industry, or identify which further training or experience must be gathered to be successful in a particular business venture (Dyke et al., 1992). Hise et al. (1983) identified the following owner characteristics as variables that can have an impact on store success: age, annual income, marital status, number of children, educational level, numbers of hours worked per week, experience in retailing, experience in present position, and experience with present employer. Previous research suggests that older, married managers with more children are likely to be more committed to their jobs, and therefore more productive. Bates (1990) found that new business owners over the age of 55 are least likely to survive commercially, whilst those in the age group of 45-54 are most likely to succeed. In firms in the technology industry, Stuart and Abetti (1990) found no significant correlation between age and business performance, or between age and entrepreneurial experience. Dyke et al. (1992) identified seven independent variables to assess owners' experience and potential for success, but when testing these variables against six financial performance measures over five industries in a sample of 386 firms, the results were as heterogeneous as the backgrounds of the owners themselves. Mode of acquisition, whether the parents of the individual were entrepreneurs, and level of education played an insignificant role in determining the success of the owner in most industries, while the experience of having previously run a business seemed unimportant in general (Dyke et al., 1992). However, it was found that previous managerial experience and previous experience with the product or service, and previous involvement with business start-ups correlated positively with firm performance across all five industries. Keeley and Roure (1990), in contrast, found that the characteristics of the entrepreneur had no influence on firm performance, as measured by industry experience, management experience, start-up experience and level of education.

Duchesneau and Gartner (1990) demonstrated that previous start-up experience, managerial experience and broad business experience played a positive role in the success of the entrepreneur, and added mode of acquisition, level of education and the influence of entrepreneurial parents as factors driving potential entrepreneurial success, while Stuart and Abetti (1990) identified previous experience in the entrepreneurial role, as reflected through involvement with new ventures, as having the highest correlation with firm success among a number of firm and environmental variables. However, this variable was highly correlated with previous entrepreneurial experience, indicating that the true predictor of potential entrepreneurial success could in fact be the level of experience in senior management within entrepreneurial undertakings. Surprisingly, it was found that level of experience played an insignificant role in firm success, indicating that it is rather the type of experience that is important when assessing the potential of an entrepreneur (Stuart \& Abetti, 1992).

Bates (1990) found little evidence that having entrepreneurial parents would result in a higher business success rate. Duchesneau and Gartner (1990), however, demonstrated that successful entrepreneurs were likely to have had entrepreneurial parents, arguing that these individuals had been exposed to the behaviours and attitudes necessary to make a success of an enterprise. Furthermore, these successful entrepreneurs had more realistic expectations of business ownership than entrepreneurs without entrepreneurial parents.

Dyke et al. (1992) hypothesised that the level of education required could be linked to the type of industry the person enters, and found a significant negative relationship between success in the food retail industry and level of education. This could mean that food retail does not necessitate a high level of education to be a successful owner - it could in fact be a deterrent to success. Stuart and Abetti (1990) supported the negative correlation between level of education and firm performance, while simultaneously pointing out a negative relationship between education and entrepreneurial experience. This might mean that the best learning school for entrepreneurs is on the 'shop floor', rather than in the classroom. In contrast, Bates (1990) concluded that the level of owner education was the strongest "human capital variable" in determining business survival. This finding was supported by a review of U.S. census data in 1996 by Fairlie and Meyer (Vecchio, 2003) by revealing a strong positive correlation between entrepreneurship and education.

Bates (1990) demonstrated that the levels of financial capital inputs are strong determinants of business success, irrespective of the level of education of the entrepreneur. This view was supported by Duchesneau and Gartner (1990) who found that high levels of seed capital were undoubtedly linked with firm success, specifically in markets where investments in fixed assets could deliver economies of scale. Osborne (1995) emphasised that the direct cause of new venture failure was often due to insufficient capital, but that a weak business model and ineffective execution often contributed to the dissipation of capital. It was also found that level of owner education played a major role in determining the amount that banks and other financial institutions were willing to lend to the formation of a small business (Bates, 1990) Therefore, highly educated entrepreneurs had greater access to capital inputs when starting a small business, which explains the finding by Bates (1990) that highly educated entrepreneurs, leveraging larger sums of capital, were far more likely to create viable, enduring companies than comparatively poorly educated entrepreneurs using limited capital inputs. Osborne (1995) added that raising the required levels of capital often took large amounts of ingenuity and persistence, indicating that 
the personality and motivation of the individual might play a role similar to education in gaining access to capital.

According to Jovanovic (Bates, 1990) business start-ups are characterised by a certain amount of managerial uncertainty, and the managerial skills of the owners are developed over time as they adjust to their strengths and weaknesses. Accordingly, Bates (1990) argued (and demonstrated) that potential new business owners might avoid this managerial uncertainty associated with start-ups, by buying an existing business, therefore benefiting from the managerial procedures entrenched in the enterprise. This was in contrast to the findings of Duchesneau and Gartner (1990) who argued that failure was almost guaranteed when the firm was purchased. They reasoned that such firms were purchased by unemployed managers, who ended up buying firms in a weak competitive position. The sellers exploited the lack of industry and competitor information, and buyers relied heavily on historical financials when making the purchase decision, only to find the historical figures did not reflect the current and future competitive environment of the firm. Osborne (1995) established that the size of the company or mode of acquisition was irrelevant in determining entrepreneurial success, which rather hinged on the ability of the individual to meet the needs of the external environment, highlighting the importance of entrepreneurs understanding both their own strengths and capabilities, as well as having an in-depth understanding of the industry within which they are operate.

In the Duchesneau and Gartner (1990) study, of the seven firms that were purchased, only the one firm that made use of outside professionals during the purchase of the firm was successful. Use of outside professionals correlated strongly with firm start-up success across all 26 firms surveyed, highlighting the importance of external expertise and advice during the start-up phase. They also found that successful firms spent on average 237 hours planning during the startup phase, versus unsuccessful firms which only spent 85 hours on average, demonstrating that planning played a critical role in the start-up or purchase of a business. Interestingly, few successful (or unsuccessful) firms had a business plan, and successful entrepreneurs rather made use of 'planning notes' when evaluating a business opportunity. Osborne (1995) emphasised the importance of developing a marketing and financial plan during the initial planning phase of a new business. Not only did this increase the prospect for new venture success, but it also assisted the entrepreneur in clarifying the business opportunity whilst strengthening the capacity to implement. Duchesneau and Gartner (1990) concluded that joint ventures, including partnerships, shareholder agreements and partnerships, were the organisational format most conducive to business success, with ready access to resources and capital. Invariably, individuals with greater start-up and business experience made use of these structures. In their study all the purchased firms were sole proprietorships, demonstrating a high incidence of business failure. They argued that this could be due to the fact that these individuals often were foreign to the industry, and unwilling or unable to make use experienced professionals or industry insiders, while also lacking an understanding of the competitive forces in the marketplace.

\section{Store operational procedures}

Fisher et al. (2006) examined the extent to which store operating procedures lead to effective execution and converted potential demand to actual sales. They isolated four execution factors that had a particularly significant impact on the ability of a store to convert potential demand into sales: 1) the availability of stock; 2) the presence of consumer assistance; 3) the helpfulness of the employees; and 4) the length of the queues at the point of payment. Stanley (2002) emphasised that companies like McDonalds and Disneyland built their reputations on exceedingly high standards of cleanliness. The same applies to supermarkets, as it had been shown that cleanliness was the most important factor to customers when shopping in a supermarket, superseding both price and quality. It was not simply cleanliness itself which made customers return, but rather the consistency of the cleanliness. One of the pillars of success in retaining customers is based on creating an emotional connection with the customer when they are in the store, and one of the key ways to achieve this is through maintaining exceptionally high levels of cleanliness.

Shrinkage, which is defined as the difference between the actual and recorded value of stock in the business, arises from staff theft, shoplifting and inaccurate stock takes (DeHoratius and Raman, 2006). Retail executives generally view this as a controllable part of the business. Large levels of shrinkage reflect poorly on the ability of the retailer to manage its stores and employees. Raman, DeHoratius and Ton (2001) found that over 65 per cent of inventory records were inaccurate at the store stock keeping unit (SKU) level in a large supermarket group and that the difference between physical and actual stock on hand was on average 35 per cent of the target level for any given product. At a different retailer it was found that sixteen per cent of sales were lost when customers could not find a product even after asking for assistance from a staff member. These items were not out of stock, but rather misplaced in a storage area, were merchandised in the wrong aisle or were lying in a back-up area. Corsten and Gruen (2003), in a large-scale study, demonstrated that when stock was not available, nine per cent of consumers simply did not make a purchase, nineteen per cent substituted with the same brand, 26 per cent substituted with a different brand, fifteen per cent delayed the purchase and 31 per cent made their purchase at another store, stressing the importance of inventory management.

Lost sales and profits due to shrinkage and inaccurate profit management could have a massive impact on the financial success of any business, and could cause lasting reputational brand damage. According to Hollinger and Langton (2004), the U.S. retail industry lost an estimated 33 billion dollars in shrinkage in 2002 (Dehoratius and Raman, 2006). Raman et al. (2001) found that inventory inaccuracy at the store level resulted in a reduction in profit by ten per cent due to lost sales, while misplaced products had reduced profits by 25 per cent. Corsten and Gruen (2003) calculated that the average sales lost globally is 3.9 per cent, stressing that this was a global problem amongst retailers. They further calculated that retailers could grow earnings by five per cent simply by addressing out-of-stock issues at store level, 
highlighting the opportunity cost associated with ineffective stock management.

\section{Leadership styles}

Leadership plays an important role in the performance of the Service Profit Chain as put forward by Heskett et al. (2008). Leaders in successful companies placed emphasis on the importance of employees and customers. Larsson and Vinberg (2010) found nine common types of leadership styles in four successful companies, these being: clear strategic and visionary direction, communicating with the organisation and providing information, displaying authority and responsibility, creating a learning culture, encouraging worker conversations, taking a 'plain and simple' approach, focusing on humanity and trust, managing by walking around and using reflective personal leadership.

Leaders must assess themselves regularly to ensure they remain effective in their role. Kaplan suggested seven questions that leaders should ask to determine whether they were still heading in the right direction, specifically when they felt the business starting to deteriorate. These questions serve to focus the leader on the vision and priorities of the business, manage time effectively, give regular feedback to employees, implement succession planning, evaluate and align the business with its environment, emphasise the necessity of efficient leadership under pressure, and on staying committed to one's personal goals (Ambler, 2008).

Goleman (2000) identified six basic leadership styles, and argued that all of these have an impact on organisational climate, and can account for up to a third of financial performance. The styles are the coercive style (demand immediate compliance and obedience), the authoritative style (mobilise people behind a vision), the affiliative style (create emotional ties and harmony), the democratic style (build unity through involvement), the pacesetting style (expect top performance and self-management), and the coaching style (grow people for the future). The study stressed that successful leaders do not rely on one style of leadership, but rather use a combination of these leadership styles. All these styles are driven by a host of specific emotional intelligence skills, defined as the ability to govern ourselves and our relationships with others. Goleman (2000) highlighted five emotional intelligence competencies, namely self-awareness, self-regulation, motivation, empathy and social skills.

The literature reviewed consistently refers to two distinct types of leadership, namely transformational leadership and transactional leadership. The first is said to motivate, intellectually stimulate and inspire individuals to go beyond their own interests to achieve a shared purpose, vision or mission (Howell \& Avolio, 1993). Bass (1990) described transformational leadership as 'superior leadership', and found that transformational leaders had better relationships with both their peers and subordinates, and played a larger role in contributing to the organisation. Antonakis, Avolio and Sivasubramaniam (2003) described the five dimensions of transformational leadership as follows: 1) idealised influence (attributed) deals with the socialised charisma of the leader; 2) idealised influence (behaviour) refers to the charisma of the leader based on values, beliefs and the leaders sense of mission; 3) inspirational motivation refers to the leaders ability to energise followers through optimism, goals and by communicating clear vision; 4) intellectual stimulation refers to the amount of creativity the leader stimulates by challenging employees to use logic and find solutions to complex problems; and 5) individualised consideration considers the extent to which the leader advises, supports and cares for followers, allowing them to develop and self-actualise. Boyett (2006) found that transformational leadership was effective across cultures, and that people in different cultures had very similar ideas of what constituted a transformational leader, using words such as dedication, goal orientation, determination and intelligence to describe an effective leader.

In research covering 50 supermarkets in a large chain, it was found that managers who adopted a transformational leadership style ran stores that showed above average performance on controlling costs, profit levels, communication efficiency and innovation. Another study indicated that transformational leadership, as measured by the multifactor leadership questionnaire (MLQ), was a consistent predictor of organisational performance characteristics such as team performance, goal attainment and extra commitment from employees (Boyett, 2006). Carless, Wearing and Mann (2000) developed the Global Transformational Leadership scale (GTL), with the aim to construct a short, reliable and valid instrument with which to measure the transformational capabilities of the leader. Through an extensive examination of the related literature, they developed seven key areas which cover the behaviour of a transformational leader. They found that a transformational leader 1) communicates a vision to subordinates; 2) develops employees; 3) provides support; 4) empowers employees; 5) is innovative; 6) leads by example; and 7) is charismatic. Carless et al. (2000) found that charisma is one of the most important elements of transformational leadership, suggesting that it is often a predictor of effective leadership. Boyett (2006) conducted extensive global research into the science of leadership, and found that effective leaders were charismatic, inspirational, considerate, stimulating and rewarded accomplishment frequently and openly. Kirkpatrick and Locke (1996) extracted three common components across the charismatic and transformational leadership theories, namely 1) the leader's ability to communicate a vision; 2) the leader's ability to implement a vision; and 3) the use of a charismatic communication style by the leader. Importantly, communicating and implementing a vision was found to have the most profound impact on follower motivation and it had been shown that the charismatic and considerate leadership of supermarket managers had a massive impact on financial performance and store climate (Hur \& Wilderom, 2008). Vecchio (2003) argued that it was vital for the entrepreneur to be able to instil a sense of motivation and inspiration in employees, especially considering the uncertainties often experienced under start-up conditions, stressing that charisma and vision played a crucial role in entrepreneurial leadership.

Transactional leadership refers to a relationship based on transactions between the leader and the follower from which 
each party benefits. In this relationship, leaders identify and satisfy the needs of followers, whilst at the same time satisfying their own needs (Polat, 2008). Transactional leadership makes use of a contingent reward and management-by-exception approach (Van Eeden, Cilliers \& van Deventer, 2008). Under contingent reward, the leader sets out the tasks that must be completed by the employee, in order for the employee to receive an award or avoid some form of punishment. In essence, it can be described as telling someone what to do, and then paying him/her on successfully completing of the task. The success of the approach depends on the value of the reward for the subordinates. Vecchio (2003), showed that entrepreneurs were consistently more task motivated than managers in small business, indicating that transactional leadership might be the preferred style of leadership in a smaller business.

Another form of transactional management is managementby-exception, whereby the leader focuses on finding mistakes, exceptions and irregularities in normal operating procedures, company policy or general rules and regulations, and then takes remedial action when any of these events occur (Van Eeden et al., 2008). Bass (1990) found that transactional leadership often lead to mediocre organisational results and employee performance.

Laissez-faire leadership sees the leader absent from the leadership role, avoiding critical leadership tasks such as goal setting and decision making, and leaving all responsibility for the work to the employees themselves (Van Eeden et al., 2008). It was found that the impact on subordinates would generally be negative when the absence of the leader is based on factors such as a lack of skills or motivation. However, in other instances, it is argued that laissez-faire leadership gives a sense of empowerment, and can form a critical part of an effective transformational leadership style (Hur \& Wilderom, 2008). The key difference between transformational and transactional leadership is the process used to motivate subordinates and the type of goals that are set (Hur \& Wilderom, 2008). A convincing argument for using a combination of transformational and transactional leadership styles comes forth in the literature. Van Eeden et al. (2008) found individualised consideration as being the link in moving from a transactional to transformational leadership style. This called for a focus on the development of individual subordinates. Hur and Wilderom (2008) argued that the service industry, like grocery retail, needs motivated and committed employees to deliver superior service to customers with the aim of creating customer loyalty, which can be best achieved through a transformational style of leadership. However, the literature reviewed suggests that transactional leadership, which relies on high levels of control, standardisation, formalisation and efficiency, lends itself well to the grocery retail environment. Boyett (2006) talked of the 'the augmentation effect', where the effectiveness of transformational leadership could be enhanced by combining it with contingent reward behaviour.

\section{Employee motivation}

J.W. Marriot, founder of the Marriot hotel chain, famously said that "you can't make happy guests with unhappy employees" (Silvestro \& Cross, 2000). Heskett, Sasser and Schlesinger (1997) described the 'satisfaction mirror', indicating that happy employees reflected in happy customers. According to the service profit chain, employee satisfaction drives both employee loyalty and productivity, and internal service quality in turn drives employee satisfaction. Foster, Whysall and Harris (2008) found that employee loyalty plays a critical role in keeping down costs and combating skills shortages in the retail industry. Internal service quality is determined by the feelings that employees have towards their co-workers, firms and jobs, and is driven by superior support services and company policies that allow employees to deliver on customer needs (Stodnick, 2005). These support services and policies include employee development programmes such as training, empowerment, and feedback and reward systems.

Esbjerg, Buck and Grunert (2010) conducted a study on how to keep low-wage store level type jobs, such as till operator and sales assistant, interesting. They found that employees had to enjoy coming to work, and it was for this reason that the retail human resource managers who were surveyed, stressed the social aspects of work as important for creating happy employees. All retailers questioned provided a budget for staff social initiatives in an attempt to create a good atmosphere and team spirit at work. Concentrating on the social aspects was also found to compensate for the lack of training and development and poor wages offered in the lower rungs of grocery retail jobs, whereas managers and aspiring managers received extensive training and career development opportunities with decent salaries. Foster et al. (2008) found that some employees even stayed with their employers due to social factors, such as the bonds they have formed with fellow employees, customers and the retailer.

Stodnick (2005) argued that companies should move away from taking a short-term, transitional view to traditional human resource activities, but should rather take a longterm, holistic view to ensure that meaningful relationships were built with employees. By investing in employees with a long-term relationship building approach in mind, companies could develop their employees into a core competence which could be leveraged for a sustainable competitive advantage. Allen and Grisaffe (2001) advocated the use of staff training, development and team-working to motivate employees to remain in long-term employment, thereby bringing down the costs associated with staff attrition in the retail industry and hence strengthening the competitive position of the company (Foster et al., 2008).

Payne, Holt and Frow (2001) examined the relationship between customer value, employee value and shareholder value in the context of relationship marketing. Of specific interest for this study, is the relationship between the employee and the other two stakeholder groups. They found that to create employee value, there needs to be employee satisfaction, employee retention and loyalty, employee productivity, employee commitment, strong leadership and internal service quality. Satisfying all these dimensions of 
employee value, would result in a positive customer experience, which in turn would motivate them to continue purchasing from the business.

Stodnick (2005) identified two international models that had been developed to explain the relationship between employee satisfaction, customer satisfaction and business success. The model on which the Malcolm Baldridge National Quality Award (MBNQA) is based, theorises that the development of the human resources in a company is part of a 'system' that ultimately drives business success. It aims to achieve this by employee training, effective communication and people skills development. The European Excellence Quality Model (EEQM) is based on very much the same principles, linking the three key stakeholder groups of customers, employees and the business. Again, achieving business success is seen as an indirect result of supportive human resource development policies aimed at developing employees.

In food retail, it has been found that employee satisfaction and loyalty are not always directly correlated with higher levels of customer satisfaction and loyalty (Silvestro \& Cross, 2000). In fact, the study by Silvestro and Cross (2000) showed that the highest performing stores (in terms of productivity and profitability) were the worst places to work (measured by staff absenteeism and staff turnover), showing a negative correlation between productivity and internal service quality. Counter intuitively, this means that the stores with the happiest employees were the least productive and least profitable. Further research by Silvestro and Cross (2000) revealed that smaller stores seemed to offer a more positive working environment for the staff. Research amongst managers in the grocery retail industry provided more evidence as to why nurturing employee satisfaction did not necessarily lead to higher profits and turnover. Retail managers identified two types of store archetypes, namely "Achieving" stores and "Coasting" stores, where "Achieving" stores suffered low levels of employee satisfaction, and "Coasting" stores enjoyed high levels of employee satisfaction. "Achieving" stores tended to enjoy high levels of profitability and turnover, but demanded much more emphasis on the enforcement of store standards, supervision of staff, and a work environment which was faster paced and more stressful. "Coasting" stores were identified as stores with lower levels of profitability and turnover, which meant that staff worked at a more leisurely pace with more time to build client relationships. In general, "Achieving" stores were identified as the larger stores, which meant that store size could be an explanation for the inverse relationship between employee satisfaction and store profitability and turnover (Silvestro \& Cross, 2000). These findings are in contrast with the results of Heskett et al. (2008), which indicated an explicit positive relationship between employee satisfaction and service potential, as measured by the staff's ability to influence customer satisfaction.

However, Silvestro and Cross (2000) pointed out that this could still not explain why higher levels of employee satisfaction are not mirrored in higher levels of customer satisfaction, which poses the question: What accounts for higher levels of customer satisfaction, and therefore store success, in the grocery retail environment? One explanation lies in the nature of the customer and the type of product on offer. People are extremely sensitive to high food prices, and factors such as convenience and availability play a large role in determining levels of customer satisfaction. However, the literature persistently finds that employee related factors play a large role in creating satisfied customers. Salmon (1989) found that employees at Walmart were motivated by being given more responsibility, whilst they also enjoyed higher levels of profit sharing, relative to the competition. Combined with this, a further emphasis on rewarding people for the work they do, helped to create an extremely cost effective company that was growing at an enviable rate, had higher profit margins, enjoyed higher sales per square foot and could offer extremely low prices. Home Depot and ToysRus have also managed to achieve a competitive advantage in the running of their warehouse centres based on an ability to motivate employees to deliver superior customer service.

Davis, Freedman, Lane, McCall, Nestoriak and Park (2006) pointed out that work in the supermarket industry was generally low paid and often unionised, with long and irregular working hours. These jobs also held little promise of training and career development. Whysall, Foster and Harris (2009) found that low wages, gender based wage discrimination, lack of career opportunities, long and irregular working hours, and a propensity to use short-term contracts were all factors which when combined, or acting independently, served as sources of dissatisfaction amongst retail employees (Esbjerg et al., 2010). To promote productivity and to motivate employees, Davis et al. (2006) proposed Internal Labour Markets (ILMs) as a means of ensuring long-term relationships with employees and subsequent loyalty. ILMs meant recruiting and promoting from inside the company, and some motivation for the use of ILMs might include the ability to influence the workforce quality, the staff turnover rate, and general efficiency and productivity. In food retail, specifically with the added skills required in service departments like the bakery, butchery and deli, retailers had recognised the strength of using ILMs in creating a highly skilled workforce. ILMs also ensured that employees developed company specific skills, which assisted in creating a highly motivated workforce (Davis et al., 2006).

Salmon (1989) argued that effective execution, based on the skills and motivation of the company's employees, was what delivered a truly competitive advantage and winning strategy. Most important was to develop the motivation and quality of lower paid rank and file employees to become highly productive and efficient, punctual and consistent in work attendance, willing to work with others in a team, have a competitive spirit, hold customer service as a priority, and be loyal to and knowledgeable about their jobs (Salmon, 1989). Esbjerg et al. (2010) identified wages, working hours, working conditions and social dimensions as areas that played key roles in driving worker satisfaction. Salmon (1989) advocated the use of profit sharing schemes, incentive pay, giving employees more freedom, flexibility and regular quantitative feedback on their personal performance and that of their peers, employing people with higher skill sets rather than employing more people, and 
avoiding unnecessary retrenchments. According to Salmon (1989), companies had to accept that higher paid and higher calibre employees would generally be more productive and therefore offset the higher wages they earned.

\section{Community involvement}

In a study to investigate the relationship between social performance and financial performance, Moore and Robson (2002) found no significant relationship between turnover and community contributions. However, a significant positive correlation was found between profitability and community contributions, which could signify that the more profit firms made, the more they contributed.

The pertinent question is whether profits are partly driven by the fact that companies make community contributions. This question is answered in part by Moore and Robson (2002) who found that all associations between social performance measures were positive, therefore suggesting that social performance measures were mutually reinforcing. This means that once a company got involved and committed to social responsibility initiatives, such as making community contributions, a self-reinforcing mechanism came into force, which lead the company further down the path of social responsibility and community involvement (Moore \& Robson, 2002). Larrabee, senior consultant at Deloitte Consulting in Houston, Texas (Kruger, 2007) described the consequence of community involvement as a 'virtuous cycle', as it benefitted the company, the volunteers, as well as the people in the community being served by the volunteers. Larrabee highlighted the importance of companies having a detailed plan for their community involvement activities, and advised that they should choose a charitable initiative that best fitted their company strategy (Kruger 2007).

According to Shaffer (2002), who investigated supermarket distribution between low-income and middle to upperincome earning communities in Los Angeles, one of the key areas of research was to understand why some supermarkets were successful in low income communities while others were not. He argued that consumers would much rather spend money in a supermarket that was seen to be putting something back into the community, than if it were to be viewed as an outside entity merely profiting from the community. Wayne D. Hoyer, Director of the Centre for Customers Insight at The University of Texas, Austin, stated that the long-term profitability of a firm relied on its ability to acquire and sustain a base of devoted customers (Shaffer, 2002). Supermarkets that were seen to be actively involved in their communities forged a much stronger bond with their consumers, building longer term relationships which would help sustain profitability. Michael Guld, president of The Guld Group and business development specialist, argued that getting involved in community activities was well motivated (Kruger, 2007). Not only did employees feel good about working for a company that was involved in the community, but customers would frequent a company that was seen to be supporting their causes and communities. Guld called this 'cause' marketing, and noted that ever more companies were realising the tangible and intangible benefits of this form of marketing (Kruger, 2007).

\section{Measuring store performance}

As competition intensifies, it becomes ever more critical for retail executives to have a clear insight into what is driving store performance, and how to measure it (Pauler, Trivedi \& Gauri, 2009). One of the problems faced by supermarket chains is in determining a legitimate and unbiased evaluation of individual store performance, keeping in mind differences in consumer living standards in the area, specific store features and the competitive environment within which the store operates. Therefore, it is necessary for retail groups to determine an equitable set of performance measures that can be used across stores operating in different markets, with different levels of competitive forces in their markets and with different physical characteristics, such as size and store features (Pauler, et al., 2009).

\section{Non-financial performance measures}

Within the group, various measures are in place to ensure that the stores are measured without bias such as location, size or competitive arena skewing the results from performance measurement systems. These measures are encapsulated within an incentivised internal competition known as the "Steps to Greatness" (STG), and the categories of variables are shown below with their respective weightings:

i) Retail operations checklist $-50 \%$

ii) Store performance $-20 \%$

iii) Loyalty performance $-10 \%$

iv) Implementation of new concepts $-10 \%$

v) Store hygiene and food safety checklist $-10 \%$

These measures do not regard any form of profitability or financial management. However, it is believed that stores that perform well on these criteria normally also outperform their peers when measured on a purely financial basis, due to the fact that good performance on the measures listed above is the result of a healthy and well-run store, which in turn satisfies customers and brings higher levels of sales and profitability to the business. The STG-measures are not mere duplicates of the explanatory variables elaborated on above and the existence of any causal structures will have to be demonstrated statistically.

\section{Financial performance measures}

Dobson (2005) identified the need to develop a set of comprehensive 'performance indicators' to assess the performance of stores in retail chains. The study suggested moving away from the traditional 'productivity measures' towards indicators more descriptive of store and group success. Dobson (2005) argued that the starting point to developing such indicators was to understand the key elements of efficiency improvements in retail which can be measured against selected store and business level data to build up a clear, inclusive picture of store performance. Therefore, the variables to be studied had to be identified before the performance measures could be developed.

Reinartz and Kumar (1999) set out to explain the effects of store, consumer, competitor and market characteristics on 
grocery store performance across the United States (U.S.) using a sample of 595 grocery stores. In an assessment of performance measures used in previous studies, they found that store sales, store profitability, customer loyalty, market share and store traffic had all been used as measures of store performance. Their research also showed that previous studies had differentiated between three broad measures of store performance. These were market-based performance measures (such as sales growth and market share), profitability-based performance measures (such as gross profit and return on assets) and productivity-based performance measures (such as sales per square foot). Reinartz and Kumar (1999) argued that it was valuable to study all of these performance-based variables directly as they portraid largely dissimilar phenomena. For example, a store with high sales volumes might not post high profit margins, whereas a store with low sales per square meter might be highly profitable. DeHoratius and Raman (2006) raised the importance of measuring both sales (market based) and shrinkage (performance based), as shrinkage could be one of the biggest expenses in a retail business. Kumar and Karande (2000) found that past studies had mainly used market-based performance measures (such as sales and market share), and developed a model that looked at both market-derived measures(sales) and productivityderived( sales per square feet) measures.

In a comprehensive literature review to examine the relationship between corporate social performance and financial performance in the chemical industry, Griffin and Mahon (1997) found that previous research in various industries had been extremely inconsistent in the selection of financial performance measures. The study found that 80 different measures had been used in 51 separate studies, and that selection of performance measures seemed to be based on the ease of getting the data and convenience for the researcher. The research showed that over 70 per cent of the 80 different financial performance measures were used only once in the 51 studies under review. The study also argued against the use of market derived measures such as price to earnings ratio (P/E Ratio) and market return, on the basis that these figures measured more than the pure financial performance of an organisation (Griffin and Mahon, 1997). They indicated that the most extensively used financial measures were size (via a natural logarithm based on total assets), return on assets (ROA), return on equity (ROE), asset age and five year return on sales. They subsequently used these five measures covering the areas of growth, profitability and asset utilisation. The choice of performance measures reflected the type of business being studied, as the chemical industry is highly capital intensive. This focus is also relevant in the supermarket industry, as large capital investments are required to set up a supermarket.

In a study of the United Kingdom (U.K.) supermarket industry, Moore (2001) adopted the work of Griffin and Mahon (1997) to measure success using a financial performance index based on growth in turnover, profitability, growth in earnings per share (EPS) and return on capital employed (ROCE). Moore (2001) pointed out that despite the large range of performance measures that had been identified in the literature, there seemed to be some consensus emerging that the above-mentioned were the more appropriate measures. Each one of these measures was rated on a linear scale to produce an un-weighted total, in order to produce a final performance index. Moore and Robson (2002) further developed the work done by Moore (2001) and conducted interviews with executives in the supermarket industry to validate the use of these financial measures. Executives from Tesco and Safeway accepted the measures as suitable. However, executives from Safeway mentioned that it would be helpful to incorporate sales per employee and sales per square foot in the analysis (Moore and Robson, 2002). The study by Moore (2001) used profit before depreciation, to counter the effect of differing depreciation policies. The study further measured the age of the company, the average turnover of the company, as well as the average gearing of the company over the selected period against the social performance variables.

Moore and Robson (2002) drew correlations between overall financial performances (based on the un-weighted sum of the four selected performance measures) with growth in turnover, profitability, growth in earnings per share (EPS) and ROCE. It was found that ROCE had the strongest correlation to overall financial performance, with a Spearman rank correlation of 0.930 . The authors therefore argued that should a single financial performance measure be selected, ROCE would be the most appropriate. However, the other performance measures did not correlate as strongly with overall performance, prompting the authors to suggest that subsequent studies should also make use of a combination of measures to develop a financial performance index.

Many of the authors surveyed in the literature have argued the need to either use market derived, profitability derived, or productivity derived measures, or a combination of these measures when assessing store performance. However, Cottrell (1973) pointed out the need to remove any measures which were outside the control of the store manager when assessing store performance, and determining performance goals, in a multi outlet business. Dobson (2005) made a similar argument, stating that external factors such as the relative market power of the store made the use of profit based measures flawed as measures of productivity or even efficiency, when comparing across stores in a retail group. Craig, Gosh and McLafferty highlighted the fact that the impact of the competitive environment on store performance could differ widely between stores (Reinhartz \& Kumar, 1999). In some cases, the competitive environment was found to have a positive influence on store performance, whereas in other cases it had a negative influence, while in another group there seemed to be little explanatory effect. This underscored the fact that similar performance measures used across a group of stores would reveal different results based on the impact of external factors on the stores.

Cottrell (1973) argued that there were many external factors which influenced store performance outside of manager control, such as location, store size, intensity of competition in the surrounding area, price level, distance from the supply source, and the opening hours of the store. On the other hand, the study identified the critical role of strategic planning in the selection of store location and size, and hypothesised that it might be more important to the success 
of the business than good execution and control at store level. Fisher et al. (2006) developed an econometric model through which a retailer could identify steps to increase sales and customer satisfaction. The model took into account the effects of a multitude of explanatory variables on sales, customer satisfaction and customer perceived in-stock, through collecting financial store performance data, operational data and customer satisfaction surveys. The measures selected to analyse store performance were monthly store sales, monthly unit sales, average basket size, average customer count (number of transactions), average number of products per basket and average sales per product. Fisher et al. (2006) defined payroll information as 'operational data', which suggested the need to include a measure of salary expenses to gauge the operational effectiveness of the store. Hise et al. (1983) selected three simple dependent variables to analyse performance across eighteen explanatory variables in a study on a large food supermarket group in the United States (US), namely sales volume, contribution income (gross profit minus direct expenses) and ROA. Executives from the business felt that ROA had the most value as a measure and relied heavily on it as a measure of success in their business. The focus on ROA supports the findings of Griffin and Mahon (1997), Moore and Robson (2002), and Moore (2001).

It is clear from the review of the associated literature that the selection of performance measures has to be driven by the variables being studied. It is apparent that whether a business is being assessed on both external and internal factors or on either of these independently, the measures chosen must be capable of measuring performance effectively. Table 1 summarises the relevant literature, and gives an overview of the explanatory variables and the selected performance measures. The present study has a broader focus than the majority of studies in Table 1 , but does not necessarily explore to similar depths.

This empirical study is aimed at understanding store performance drivers. The method was mainly grounded in quantitative data collection and analysis methods. However, in developing the questions for the questionnaire, interviews had to be conducted with executives and retailers, meaning that there was some qualitative data collection as part of the process. A questionnaire was designed and distributed to a sample of the 685 retailers in South Africa. Answers to these questions formed the independent variables, and the selected performance measures the dependent variables. The selected dependent variables were sales growth, profit before interest and tax (PBIT) and STG results, all measured over a three year period from 2006 to 2009.
It appears from the literature that sales growth is normally measured over a three year period, however, many of the studies surveyed do not specify the period used. Profitability is more often considered only for the current year. Moore (2001) found that previous studies had used anywhere between one and five years as a financial measurement period, mainly to eliminate the effects of unusual events contained within a single financial year. Subsequently, Moore (2001) used a three year period to compare both lagged and current performance. Griffin and Mahon (1997), on the other hand, found that a five year period was most popular in previous studies when reviewing profitability measures such as ROCE, ROA and Return on Sales. Fisher et al. (2006) gathered financial data over a 29 month period, but only used data collected in the last seventeen months of the study.

In the study conducted by Moore and Robson (2002), a three year period was used to review changes in sales growth, earnings per share growth, profitability and ROCE. Executives from Safeway pointed out that they were comfortable with this time period, as it smoothed out irregularities, whilst being lengthy enough to be of strategic importance. They found that there was no statistically significant relationship between current financial performance and lagged financial performance, implying that past financial performance was not necessarily a predictor of future performance. However, a significantly strong relationship between past levels of profitability and current profitability was noted. There is value in using a longer time period when assessing performance, specifically to analyse the sustainability of store success and hence it was decided to use a three year time period for both performance measures in assessing the performance of stores in this study.

This study had to collect information from 247 (based on sample size determination) respondents located around South Africa, and therefore using a self-administered online questionnaire was the most logical choice. A potential problem with this method is ensuring that the correct person does in fact answer the questionnaire. To counter this problem, the e-mail containing the hyperlink to the questionnaire was only sent to the selected individuals. The respondent had to select his or her store on the questionnaire, which the researcher could then match to specific owner characteristics to ensure the correct person had answered the questionnaire. 
Table 1: Summary of literature review on retail store performance

\begin{tabular}{|c|c|c|c|c|c|}
\hline $\begin{array}{l}\text { Griffin and } \\
\text { Mahon } \\
\text { (1997) }\end{array}$ & $\begin{array}{l}\text { Corporate } \\
\text { social and } \\
\text { financial } \\
\text { performance - } \\
\text { Chemical } \\
\text { Industry }\end{array}$ & $\begin{array}{ll}\text { - } & 4 \text { Social } \\
& \text { Performance } \\
& \text { Measures }\end{array}$ & $\begin{array}{ll}\text { - } & \text { Size } \\
\text { - } & \text { ROA } \\
\text { - } & \text { ROE } \\
\text { - } & \text { Asset Age } \\
\text { - } & \text { Five Year Return } \\
& \text { on Sales }\end{array}$ & $\begin{array}{ll}\text { - } & \text { Ranking } \\
\text { method }\end{array}$ & 7 firms \\
\hline $\begin{array}{l}\text { Moore } \\
\text { (2001); } \\
\text { Moore } \\
\text { and } \\
\text { Robson } \\
\text { (2002) }\end{array}$ & $\begin{array}{l}\text { Corporate } \\
\text { social and } \\
\text { financial } \\
\text { performance - } \\
\text { U.K. } \\
\text { Supermarket } \\
\text { Industry }\end{array}$ & $\begin{array}{ll}16 \text { Social } \\
\text { Performance } \\
\text { Measures }\end{array}$ & $\begin{array}{ll}\text { - } & \text { Sales Growth } \\
\text { - } & \begin{array}{l}\text { Profitability } \\
\text { (before }\end{array} \\
\text { depreciation) } \\
\text { - } & \text { Growth in EPS } \\
\text { - } & \text { ROCE }\end{array}$ & $\begin{array}{ll}\text { - } & \begin{array}{l}\text { Correlation } \\
\text { method }\end{array} \\
\text { - } & \text { Ranking } \\
\text { method } \\
\text { - } & \text { Cluster } \\
\text { analysis }\end{array}$ & 8 firms \\
\hline $\begin{array}{l}\text { Hise } \\
(1983)\end{array}$ & $\begin{array}{l}\text { Factors } \\
\text { affecting } \\
\text { performance of } \\
\text { individual chain } \\
\text { store units }\end{array}$ & $\begin{array}{ll}\text { - } & \text { Store manager } \\
\text { variables } \\
\text { - } & \text { Store } \\
\text { variables } \\
\text { - } & \text { Competitive } \\
\text { variables } \\
\text { - Location } \\
\text { variables }\end{array}$ & $\begin{array}{ll}\text { - } & \text { Sales volume } \\
\text { - } & \text { Contribution } \\
\text { margin } \\
\text { - }\end{array}$ & $\begin{array}{l}\text { Regression } \\
\text { analysis }\end{array}$ & $\begin{array}{l}132 \\
\text { stores }\end{array}$ \\
\hline $\begin{array}{l}\text { Reinartz } \\
\text { and } \\
\text { Kumar } \\
\text { (1999) }\end{array}$ & $\begin{array}{l}\text { Store, Market, } \\
\text { Consumer and } \\
\text { Competitor } \\
\text { effects on store } \\
\text { performance }\end{array}$ & $\begin{array}{ll}\text { - } & \text { Store } \\
& \text { Attractiveness } \\
\text { - } & \text { Market } \\
\text { Potential } \\
\text { - Socio } \\
\text { Economic } \\
\text { Status }\end{array}$ & $\begin{array}{l}\text { - Sales } \\
\text { - Sales per square } \\
\text { foot }\end{array}$ & $\begin{array}{l}\text { Regression } \\
\text { analysis }\end{array}$ & $\begin{array}{l}595 \\
\text { stores }\end{array}$ \\
\hline $\begin{array}{l}\text { Kumar } \\
\text { and } \\
\text { Karande } \\
(2000)\end{array}$ & $\begin{array}{l}\text { Effect of retail } \\
\text { store } \\
\text { environment on } \\
\text { retailer } \\
\text { performance }\end{array}$ & $\begin{array}{ll}\text { - } & \text { Internal store } \\
& \text { environment } \\
\text { - } & \text { Trade area } \\
& \text { demographics }\end{array}$ & $\begin{array}{ll}\text { - } & \text { Sales } \\
\text { - } & \text { Sales per square } \\
\text { foot }\end{array}$ & $\begin{array}{l}\text { Regression } \\
\text { analysis }\end{array}$ & $\begin{array}{l}646 \\
\text { stores }\end{array}$ \\
\hline $\begin{array}{l}\text { Cottrell } \\
\text { (1973) }\end{array}$ & $\begin{array}{l}\text { Environmental } \\
\text { model for } \\
\text { performance } \\
\text { management in } \\
\text { a chain of } \\
\text { supermarkets }\end{array}$ & $\begin{array}{ll}\text { - } & \text { Internal store } \\
& \text { environment } \\
\text { - } & \text { Trade area } \\
& \text { demographics }\end{array}$ & $\begin{array}{ll}\text { - } & \text { Sales } \\
\text { - } & \text { Gross Profit } \\
& \text { Margins } \\
\text { - } & \text { Direct Expenses }\end{array}$ & $\begin{array}{ll}\text { - } & \text { Regression } \\
& \text { analysis }\end{array}$ & $\begin{array}{l}37 \\
\text { stores }\end{array}$ \\
\hline $\begin{array}{l}\text { Fisher, } \\
\text { Krishnan } \\
\text { and } \\
\text { Netessine } \\
(2006)\end{array}$ & $\begin{array}{l}\text { Retail Store } \\
\text { Execution }\end{array}$ & $\begin{array}{ll} & \text { Sales } \\
\text { - } & \text { Customer } \\
& \text { satisfaction } \\
\text { - } & \text { Customer } \\
\text { perceived in- } \\
\text { stock }\end{array}$ & $\begin{array}{ll}\text { - } & \text { Store financial } \\
& \text { performance data } \\
\text { - } & \text { Customer } \\
& \text { surveys results } \\
\text { - } & \text { Operational data }\end{array}$ & $\begin{array}{ll}- & \text { Correlation } \\
\text { method } \\
\text { - Three stage } \\
\text { econometric } \\
\text { model } \\
\text { (regression) }\end{array}$ & $\begin{array}{l}437 \\
\text { stores }\end{array}$ \\
\hline
\end{tabular}

Source: Literature review research method 
A likely problem with self-administered questionnaires is a low response rate. A number of steps were taken to ensure the maximum response rate was achieved, such as formulating easily understood questions and by keeping the questionnaire as concise as possible. Furthermore, the topic was of interest to the respondents, which has been proven to increase the response rate significantly (Saunders et al., 2007). A cover letter introducing the study and the purpose of the research accompanied every invitation to partake in the questionnaire. Also, a very comprehensive introduction highlighted the confidentiality of the questionnaire, and indicated the average time of completion as fifteen minutes, which is believed to have encouraged respondents to complete the questionnaire. The flow and structure of the questionnaire specifically placed straight-forward and biographical type questions in the first few sections, and then proceeded into the more complex and personal type questions dealing with leadership and staff management. Financial information was only requested at the very end, as there was a risk of the respondents not providing the researcher with this information. By placing these questions at the end, the rest of the information had already been collected, giving the researcher enough data to work with and complete the study (Sanders et al., 2007). A company logo was placed on every page to create familiarity with the respondents. All pages used a similar font style and size, to ensure a neat and professional looking questionnaire.

The final questionnaire consisted of eight sections, with a total of 85 possible questions, split over 19 pages, as indicated in Table 2. The variables measured and used are listed in Table 4.

Table 2: Questionnaire breakdown

\begin{tabular}{l|l|c}
\hline Section & \multicolumn{1}{c|}{ Topic } & Number of questions \\
\hline Section 1 & Store details & 2 \\
\hline Section 2 & Owner \& business information & 27 \\
\hline Section 3 & Competitor variables & 10 \\
\hline Section 4 & Store operational procedures & 6 \\
\hline Section 5 & Leadership styles & 15 \\
\hline Section 6 & Staff management and motivation & 16 \\
\hline Section 7 & Community involvement & 3 \\
\hline Section 8 & Financial measures & 3 \\
\hline Source: Qu & \\
\hline
\end{tabular}

Source: Questionnaire

The questions were determined after an extensive review of the related literature on the drivers of store performance, leadership, staff management and motivation, entrepreneurial characteristics, and small business success, by evaluating internal company audit check-sheets, and by interviews with group executives and retailers. The questions explored store issues such as operational procedures, competitor variables, community involvement, leadership styles, staff management and motivation, and owner and business structure characteristics. All questions dealt with either attribute or behavioural data. Specific care was taken in the wording of the questions to ensure they were easy to understand, addressed the right topic and did not cause offence to any of the respondents. Due to the quantitative nature of the study, the questions were designed to allow for performing statistical analysis on the results. Therefore, only closed-ended questions were used, such as list, rating, category, and quantitative type questions, with no open-ended questions. In no question was the respondent given the opportunity to select 'other' or 'not sure'.

With the exception of Section 5, all questions were original and based on the findings of the researcher during the interview process and literature review. In Section 5 (Leadership Styles), the work of Carless et al. (2000) was adopted to develop the leadership questions. The first seven questions were based directly on the Global Transformational Leadership Scale (GTL), whereas the last six questions were developed out of the related leadership literature. It was decided to measure transformational leadership abilities using the GTL due to its proven validity. Cronbach's alpha was calculated to test the construct validity of the questions testing transactional and transformational leadership styles. In the case of the transformational set of questions, the construct validity of the GTL was upheld with a Cronbach alpha of 0,77 , supporting the decision to use this measure of transactional leadership styles. The transactional set of questions produced a Cronbach alpha of 0,59 , which indicates an acceptable standard of reliability in the questions and measurement of this construct.

The questionnaire was tested on a small sample of retailers and group executives to check for validity and reliability, and to gather general feedback on the questionnaire. Ten respondents were selected for the pilot sample, of which seven responded. The pilot questionnaire indicated that all questions were useful and valid in the context of this study. When talking to the individuals involved in the pilot study, it was established that they all understood the questions in a similar manner, which indicated reliability.

Simple random stratified sampling was followed, where each store owner had an equal probability of being included in the sample. The sample was stratified proportionally across the regions within which the group operates, to 
ensure that the characteristics of the sample were comparative to the overall population.

The sample size was calculated as 247 at the 95 per cent confidence level, five per cent precision and a 50 per cent variance. The number of retailers per region was calculated upon the weighting of each region in the country, which allowed for a scientific method of stratifying the retailers and the sample. Table 3 indicates the number of store owners that had to be sampled per region to ensure that the sample was approximately proportional to the entire population.

During the first month of the questionnaire being active, it was decided to draw another sample of 247 retailers due to a low response rate with the first group, effectively doubling the sample size. The final sampled number of stores was 490, with a total response of 204 stores. The final response rate was therefore 41.63 per cent. It also became apparent during the data collection phase that many stores had only been in operation for one or two years, therefore meaning that they had to be excluded from the inferential statistics for the purposes of this study, further reducing the sample size.

Early in the data collection process, it became clear that retailers were not providing the profit information (PBIT) required in the last section. Some retailers did provide the required information, however many gave figures that were visibly not real profit figures. It was also felt that retailers were discouraged from completing the questionnaire by the knowledge that they will be required to provide profit figures. Based on this, it was decided to remove this section completely with the intent of increasing the response rate and putting the retailers at ease.

To summarise, a review of the associated literature indicated that there is evidence to support the areas of owner and business characteristics, store operational procedures, leadership styles, staff management and motivation, and community involvement as drivers of store success. Discussions with group executives supported these findings, while also highlighting the need to include competitor variables as part of the study. The literature also validated the use of sales growth and PBIT as measures of success in supermarkets, and suggested measuring these figures over a three year period. However, PBIT was not included as a measurement of store success in this study due to data collection challenges. Pauler et al. (2009) highlighted the importance of having a measure of success that is not influenced by the external environment, and the STG results figures were used for this purpose with good effect.

Table 3: Sample size required per region

\begin{tabular}{l|c|c|c|c}
\hline Distribution areas & Total stores & Retailers & $\begin{array}{c}\text { Percentage of Total } \\
\text { group }\end{array}$ & $\begin{array}{c}\text { Sample size required per } \\
\text { region }\end{array}$ \\
\hline Eastern Cape & 97 & 76 & $11 \%$ & 28 \\
\hline Kwazulu Natal & 160 & 126 & $18 \%$ & 45 \\
\hline Lowveld & 37 & 29 & $4 \%$ & 11 \\
\hline North Rand & 157 & 124 & $18 \%$ & 45 \\
\hline South Rand & 251 & 198 & $29 \%$ & 71 \\
\hline Western Cape & 167 & 132 & $19 \%$ & 47 \\
\hline Totals & 869 & 685 & & 247 \\
\hline
\end{tabular}

Source: Calculated from company data.

\section{Research findings}

\section{Bivariate analysis}

A total of 81 bivariate tests - were performed on each of the variables Steps to Greatness and Sales Growth to establish significant differences or linear relationships, with thirteen significant findings for STG and none for sales growth. It was further established that sales growth was significantly related to STG $(\mathrm{p}=0,0124)$, but explaining only about 4 per cent of the variation in sales growth. Table 4 provides evidence that the sales growth variable is independent of all selected explanatory variables.

\section{Owner and business characteristics}

The p-value of 0.0000 of the ANOVA test resulting from Variable 1, provides evidence of differences between the average STG results achieved per region. The Lowveld region did not form part of this test due to insufficient data.
Closer inspection of the differences in the means between the regions indicates that the Eastern Cape has the highest STG results. It can therefore be concluded that the Eastern Cape stores are better managed, and that standards are in general higher in these stores.

Dyke et al. (1992) found that the entrepreneurial background of the parents and the owners' levels of education were not related to successful business outcomes. These findings were corroborated in the present study, where the levels of education were diverse, with the majority of owners having graduated from high school. Dyke et al. (1992) concluded that the type of previous of the owner did play a significant role in predicting success. This finding could not be confirmed in the present study, although experience in marketing was significantly inversely related to store success. It could be argued that individuals with marketing experience choose to focus their talents into different areas, such as sales growth and profitability, at the expense of the STG results. In fact, 
experience has shown that some retailers in this group consciously ignore some of the measurements of the STG, allowing them to focus their efforts and budgets into areas more important to them. Individuals with marketing experience may focus more of their attention into areas such as media presence and community involvement, neither of which is specifically considered by the STG measurement. The general inability of experience to predict success can possibly be explained by the work of Reuber, Dyke and Fischer (1990), which showed that it is not the level or type of experience and education that play a role in success, but rather the individual's ability to learn from experiences. Therefore, it could be said that, if the individual has the ability and motivation to learn from experiences, then the shop floor could be the best place to learn how to become a successful retailer. This argument is strengthened by the fact that the number of fields in which an owner demonstrates experience, is significantly inversely related to store success.

Family involvement, number of stores under ownership, living proximity, legal ownership structure, number of partners and previous experience in similar made no significant contribution in the explanation of store success.

\section{Competitor variables}

The purpose of the study was to focus on the internal, or controllable, factors of store success. However, as highlighted by Cottrell (1973), it is critical to measure some of the influences of the external environment, which could be called the uncontrolled variables, when assessing store performance. Although not exhaustive, the three questions asked in the questionnaire resulted in some interesting findings. Thirty-three per cent of the retailers in the sample had a direct competitor in the same mall. For those who did not have a competitor in the mall, 75 per cent had a competitor within a five kilometre radius of the store. These findings point out that the food retail landscape in South Africa is densely traded, highlighting that new growth might come from the less densely traded areas.

According to Reinartz and Kumar (1999), customers are disproportionally pulled to stores in their immediate areas. This is traditionally seen as a strength of the group, with the majority of the stores being located in the neighbourhood areas. However, with such a high concentration of supermarkets in a five kilometre radius, it seems that the group is not alone in the local neighbourhood, and the group will need to be cognisant of this when designing marketing campaigns and strategies.

The presence of competitors in the same mall as the group's stores had no negative effect on sales growth, indicating the irrelevance of having a competitor in the same mall. This may reflect the observation that in some cases, turnover actually increases when a certain competitor enters the mall. Neither the competitor density in the mall, nor the individual presence of seven different competitors could be associated with business success. However, the distance from the nearest competitor, did show a significant positive correlation with store success, confirming the success of a strategy of physically distancing yourself from competitors. This conclusion should, however, be moderated by taking cognisance of client density.

\section{Table 4: Test results}

\begin{tabular}{|c|c|c|c|c|}
\hline Question & Variable & Test & STG p-value & $\begin{array}{c}\text { Sales growth p- } \\
\text { value }\end{array}$ \\
\hline 1 & Regions (5 regions) & ANOVA & $0,0000^{*}$ & 0,6975 \\
\hline 2 & Store types (3 types) & ANOVA & 0,5135 & 0,0952 \\
\hline 3 & Age & Correlation & $0,0179 *$ & 0,3545 \\
\hline 4 & Education level (ordinal) & Correlation & 0,3659 & 0,4388 \\
\hline 5 & Owner home proximity $(5 \mathrm{~km})$ (binary) & t-test & 0,7898 & 0,4295 \\
\hline 6 & Prior industry experience (binary) & t-test & 0,4001 & 0,6197 \\
\hline 7.1 & General management experience (binary) & t-test & 0,1803 & 0,4591 \\
\hline 7.2 & Technical experience (binary) & t-test & 0,6999 & 0,7075 \\
\hline 7.3 & Marketing experience (binary) & t-test & $0,0213 *(-)$ & 0,4854 \\
\hline 7.4 & Financial experience (binary) & t-test & 0,3050 & 0,3533 \\
\hline 7.5 & Operations experience (binary) & t-test & 0,7958 & 0,0523 \\
\hline 7.6 & Consulting experience (binary) & t-test & 0,4314 & 0,9381 \\
\hline 8 & Number of skills (ordinal) & Correlation & $0,0068 *(-)$ & 0,3350 \\
\hline 9 & Store age (quantitative) & Correlation & 0,7250 & 0,1669 \\
\hline 10 & Present ownership length (quantitative) & Correlation & 0,4627 & 0,3213 \\
\hline 11 & Build or buy (binary) & t-test & 0,8279 & 0,2489 \\
\hline 12 & Family involved (binary) & t-test & 0,3300 & 0,6691 \\
\hline 13 & Background of parents (binary) & t-test & 0,8900 & 0,4116 \\
\hline 14 & Ownership structure (categories) & ANOVA & 0,3848 & 0,4177 \\
\hline 15.1 & Closed corporation (binary) & t-test & 0,0815 & 0,5788 \\
\hline 15.2 & Partnership (binary) & t-test & 0,6048 & 0,6198 \\
\hline 15.3 & Trust (binary) & t-test & 0,1067 & 0,4158 \\
\hline 15.4 & Private company (binary) & t-test & 0,4357 & 0,0548 \\
\hline 15.5 & Sole proprietor (binary) & t-test & 0,6329 & 0,3069 \\
\hline 15.6 & Public company (binary) & t-test & 0,1931 & 0,9761 \\
\hline 16 & Number of partners (quantitative) & Correlation & 0,1788 & 0,8214 \\
\hline 17 & Number of businesses started (quantitative) & Correlation & 0,0841 & 0,4912 \\
\hline
\end{tabular}




\begin{tabular}{|c|c|c|c|c|}
\hline 18 & Years of franchise ownership (quantitative) & Correlation & 0,6472 & 0,9778 \\
\hline 19 & Quantity of stores owned (quantitative) & Correlation & 0,1303 & 0,9393 \\
\hline 20 & Competitors in mall (binary) & t-test & 0,7817 & 0,5220 \\
\hline 21.1 & Competitor A (binary) & t-test & 0,5321 & 0,4087 \\
\hline 21.2 & Competitor B (binary) & t-test & 0,7595 & 0,8682 \\
\hline 21.3 & Competitor C (binary) & t-test & 0,3387 & 0,6580 \\
\hline 21.4 & Competitor D (binary) & t-test & 0,5048 & 0,6446 \\
\hline 21.5 & Competitor E (binary) & t-test & 0,3516 & 0,3157 \\
\hline 21.6 & Competitor F (binary) & t-test & 0,3650 & 0,8933 \\
\hline 21.7 & Competitor G (binary) & t-test & 0,1424 & 0,5547 \\
\hline 22 & Competitor density & Correlation & 0,1743 & 0,6747 \\
\hline 23 & Distance to competition (quantitative) & Correlation & $0,0267 *$ & 0,7515 \\
\hline 24 & Product quality manager (binary) & t-test & 0,1375 & 0,2390 \\
\hline 25 & Category management (binary) & t-test & $0,0094 *$ & 0,3381 \\
\hline 26 & Detailed ordering systems (binary) & t-test & 0,8048 & 0,8160 \\
\hline 27 & Frequency of store department stock take (quantitative) & Correlation & 0,1521 & 0,5263 \\
\hline 28 & Frequency of store stock take (quantitative) & Correlation & $0,0125 *$ & 0,7702 \\
\hline 29 & Percentage time on floor (quantitative) & Correlation & 0,5971 & 0,6698 \\
\hline 30.1 & Clear vision communicated (ordinal) & ANOVA & 0,4916 & 0,9892 \\
\hline 30.2 & Encourage staff development (ordinal) & ANOVA & 0,4170 & 0,7708 \\
\hline 30.3 & Public employee recognition (ordinal) & ANOVA & 0,6150 & 0,7681 \\
\hline 30.4 & Empower employees (ordinal) & ANOVA & 0,7989 & 0,1204 \\
\hline 30.5 & Encourage new thinking (ordinal) & ANOVA & 0,8465 & 0,6489 \\
\hline 30.6 & Employees clear on values (ordinal) & ANOVA & $0,0374 *$ & 0,8728 \\
\hline 30.7 & Respect and inspire employees (ordinal) & ANOVA & 0,5340 & 0,4056 \\
\hline 31 & Transformation skills (quantitative) & Correlation & 0,0637 & 0,3130 \\
\hline 32.1 & Main focus on maintenance (ordinal) & ANOVA & 0,5666 & 0,9190 \\
\hline 32.2 & Lead by specific incentives (ordinal) & ANOVA & 0,9323 & 0,8403 \\
\hline 32.3 & Manage deviators from standards (ordinal) & ANOVA & $0,0377 *$ & 0,9378 \\
\hline 32.4 & Exchange reward for effort (ordinal) & ANOVA & 0,5463 & 0,1826 \\
\hline 32.5 & Manage hands-off (ordinal) & ANOVA & 0,7659 & 0,2773 \\
\hline 32.6 & Delegate maximally (ordinal) & ANOVA & 0,2773 & 0,9762 \\
\hline 33 & Transactional skills (quantitative) & Correlation & 0,4168 & 0,7531 \\
\hline 34 & Staff induction programmes (binary) & t-test & 0,5882 & 0,5017 \\
\hline 35 & Staff performance management (binary) & t-test & 0,3969 & 0,9464 \\
\hline 36 & Reviewed performance management (binary) & t-test & $0,0241 *$ & 0,4934 \\
\hline 37 & Financial incentives provided (binary) & t-test & 0,5938 & 0,2493 \\
\hline 38 & Ownership/share system for staff (binary) & t-test & 0,0635 & 0,8560 \\
\hline 39 & Short-term staff loans (binary) & t-test & 0,3243 & 0,3281 \\
\hline 40 & Long-term staff loans (binary) & t-test & 0,1767 & 0,4840 \\
\hline 41 & Medical aid scheme (binary)) & t-test & 0,9217 & 0,5079 \\
\hline 42 & Pension fund (binary) & t-test & 0,5764 & 0,2560 \\
\hline 43 & Savings scheme (binary) & t-test & $0,0410 *$ & 0,5858 \\
\hline 44 & Provident fund (binary) & t-test & 0,1421 & 0,2158 \\
\hline 45 & Subsidised transport (binary) & t-test & 0,4078 & 0,3764 \\
\hline 46 & Subsidised housing (binary) & t-test & $0,0454 *(-)$ & 0,7170 \\
\hline 47 & Annual bonus (binary) & t-test & 0,2826 & 0,1146 \\
\hline 48 & Guaranteed $13^{\text {th }}$ cheque (binary) & t-test & 0,4465 & 0,4907 \\
\hline 49 & Yearly staff party (binary) & t-test & 0,4420 & 0,1660 \\
\hline 50 & Total benefits (quantitative) & t-test & 0,5127 & 0,2106 \\
\hline 51 & Labour unrest (binary) & t-test & 0,2406 & 0,0743 \\
\hline 52 & Yearly community budgets (binary) & t-test & 0,5220 & 0,3474 \\
\hline 53 & Community action plan (binary) & t-test & $0,0169 *$ & 0,9836 \\
\hline 54 & Involved in community activities & t-test & 0,8643 & 0,9288 \\
\hline
\end{tabular}

A minus in brackets indicates a contrary to expectation significant result. An asterisk indicates significance at the 5 per cent level

\section{Store operational procedures}

Stanley (2002), Canada, Cotton and Cachon (2007) and Berry (2001) all found that general cleanliness and health and hygiene standards are in some way associated to customer satisfaction, and that it can be a key strategic variable in the competitive battle for customer loyalty. It is noted that 78 per cent of the retailers in the sample take the management of this function seriously enough to allocate a senior store manager to managing store health and hygiene standards. The widespread presence of this function may account for the fact that the presence thereof cannot significantly explain the successes.

Category management, as manifested by the introduction of the CATMAN system, does significantly relate to store successes and so does the frequency of store stock takings, which indicates stricter operational procedures in the store. 


\section{Leadership styles}

Assessing leadership styles using a short, self administered questionnaire will always be challenging. Although mostly not statistically related to any of the dependent variables, the data shows that retailers in the study employ a good mix of transformational and transactional leadership styles, which have been shown to deliver sustainable and competitive performance (Nel, 2008). This kind of leader is described as people-driven, with the result being sustainability, organisational resilience and competitiveness. Leadership styles of store owners qualify for much wider research, as there is much diversity and individuality present in the population of store owners.

One significant dimension which stands out is the positive effect that the clear enunciation of the values of the owner and the business has on store performance. Another is the clarity of goal setting combined with the continual management of the deviation from the set goals

\section{Staff management and motivation}

It is common cause that good staff management practices include aspects like induction programmes, performance management an and reviewed performance management. The last of these was shown to significantly contribute to store successes. This means that it is beneficial to put employees through the performance management process more than once a year. It can also be hypothesized that happy employees will create happy customers. Many incentives exist by means of which work satisfaction of employees can be advanced, amongst other financial incentives, co-ownerships systems , short- and long-term staff loans, medical aid and pension fund membership, savings schemes, provident funds, subsidised transport and housing, yearly bonus and a yearly staff party. Of these two made a significant contribution to store performance - the availability of a staff savings scheme, which has a positive effect, and subsidised housing on performance is, however, negative - indicating that the cost of the housing provision probably competes with the cost of maintaining a store at high levels.

\section{Community involvement}

Moore and Robson (2002) found that community involvement has a self re-enforcing mechanism, where stores that are involved in their communities tend to get more involved, and stay involved, than those who do not get involved in their communities and Kruger (2007) argued the importance of having a detailed plan for community involvement activities. The presence of such a plan was significantly positively associated with STG results. Ninetyfour per cent of the retailers in the sample said that they get involved in the community as opportunities present themselves. This is positive, as it allows the store to respond to the needs of the community and it leads to a dynamic where business sustainability and community improvement interact positively.
Table 5: Results of stepwise regression analysis

\begin{tabular}{l|l|c|c}
\hline \multicolumn{1}{c|}{ Section } & \multicolumn{1}{|c|}{ Variable } & Coefficient & p-value \\
\hline 3 & Intercept & 0,5858 & 0,0000 \\
\hline 2 & $\begin{array}{l}\text { Distance to } \\
\text { competition }\end{array}$ & 0,0005 & 0,0220 \\
\hline 2 & $\begin{array}{l}\text { Marketing } \\
\text { experience }\end{array}$ & $-0,1064$ & 0,0092 \\
\hline 6 & Age & 0,0028 & 0,0221 \\
\hline 6 & $\begin{array}{l}\text { Frequency of } \\
\text { stock take }\end{array}$ & 0,0174 & 0,0108 \\
\hline 6 & $\begin{array}{l}\text { Savings } \\
\text { scheme }\end{array}$ & 0,0836 & 0,0815 \\
\hline & $\begin{array}{l}\text { Subsidised } \\
\text { housing }\end{array}$ & $-0,1179$ & 0,0813 \\
\hline
\end{tabular}

The regression equation contains interval, ordinal and nominal data and explains 21,04 per cent of the variation in the dependent variable STG. The significance level for the inclusion of variables was set at ten per cent.

The multivariate results are a consistent reflection of the results of the bivariate analyses. Variables from three different categories of explanatory variables are retained owner characteristics, competitor characteristics and staff management and motivation. Distances to competition, age, frequency of stock take and the presence of a savings scheme all lead to improved performance, while marketing experience and subsidised housing detracts from the performance measure.

\section{Conclusion}

There are many variables, both from the external and internal environment, that combine to determine the long run success of both the retailer and the supermarket. In particular, it has been argued that it is a combination of the strengths, and weaknesses, present in the external and internal environment that conspires to give a particular outcome. The human element will always play a large role in store success, both in terms of the store owner's leadership style, the management styles of the senior managers, the connection with the customers and community, negotiating skills when dealing with suppliers and stakeholders, and the level of motivation and productivity in the workforce. A store unable to successfully address these areas is unlikely to be a success in the long run, regardless how favourable the variables present in the external environment.

It has been demonstrated that good internal managerial practices as represented by the steps-to-greatness measurement scale, do positively relate to sales growth, albeit to a very low extent. The human element, as defined above does explain, to a slight extent, the internal success measurements, but over the short run, does not explain sales growth, where the highly variable external environment seems to dominate.

\section{References}

Antonakis, J., Avolio, B.J. \& Sivasubramaniam, N. 2003. 'Context and leadership: An examination of the nine-factor 
full-range leadership theory using the multifactor leadership questionnaire', The Leadership Quarterly, 14:261-295.

Ambler, G. 2008. 'Seven critical questions to assess your leadership.'. [online] URL:

http://www.thepracticeofleadership.net/2008/10/19/seven-

critical-questions-to-assess-your-leadership/. Accessed: 19 May 2010.

Bass, B.M. 1990. 'From transactional to transformational leadership: Learning to share the vision', Organisational Dynamics, 18(3):19-31.

Bates, T. 1990. 'Entrepreneur human capital inputs and small business longevity', The Review of Economics and Statistics, 72(4):551-559.

Berry, L.L. 2001. 'The old pillars of new retailing', Harvard Business Review, April:131-137.

Boyett, J.H. 2006. 'The proof that transformational leadership works'. Boyett \& Associates. [online] URL: http://www.jboyett.com/files/The_Proof_That_Transformati onal_Leadership_Works.pdf. Accessed: 17 May 2010.

Carless, S.A., Wearing, A.J. \& Mann, L. 2000. 'A short measure of transformational leadership', Journal of Business and Psychology, 14(3):389-405.

Corsten, D. \& Gruen, T. 2003. 'Desperately seeking shelf availability: An examination of the extent, the causes, and the efforts to address retail out-of-stocks', International Journal of Retail \& Distribution Management, 31(2):605617.

Cotton, B. \& Cachon, J. 2007. 'Resisting the giants: Small retail entrepreneurs against mega-retailers - An empirical study', Journal of Small Business and Entrepreneurship, 20(2):135-150.

Cottrell, J.L. 1973. 'An environmental model for performance measurement in a chain of supermarkets', Journal of Retailing, 49(3):51-63.

Davis, E.E., Freedman, M., Lane, J., B. McCall, B., Nestoriak, N. \& Park, T. 2006. 'Supermarket human resource practises and competition from mass merchandisers', American Journal of Agricultural Economics, 88(5):1289-1295.

DeHoratius, N. \& Raman, A. 2006. 'Store manager incentive design and retail performance: An exploratory investigation,' Manufacturing \& Service Operations Management, 9(4):518-534.

Dobson, P. 2005. 'Retail performance indicators in the nation of shopkeepers', International Review of Retail, Distribution and Consumer Research, 15(3):319-327.

Duchesneau, D.A. \& Gartner, W.B. 1990. 'A profile of new venture success and failure in an emerging industry', Journal of Business Venturing, 5:297-312.
Dyke, L.S., Fischer, E.M. \& Reuber, A.R. 1992. 'An interindustry examination of the impact of owner experience on firm performance', Journal of Small Business Management, October:72-87.

Esbjerg, L., Buck, N. \& Grunert, K.G. 2010. 'Making working in retailing interesting: A study of human resource management practises in Danish grocery retail chains', Journal of Retailing and Consumer Services, 17:97-108.

Fisher, M.L., Krishnan, J. \& S. Netessine, S. 2006. Retail store execution: An empirical study. The Wharton School, University of Penssylvania, December.

Foster, C., Whysall, P. \& Harris, L. 2008. 'Employee loyalty: An exploration of staff commitment levels towards retailing, the retailer and the store', The International Review of Retail, Distribution and Consumer Research, 18(4):423-435.

Garson, G.D. 2010. 'Logistic regression: Statnotes. North Carolina State University, 20 May. [online] URL: http://faculty.chass.ncsu.edu/garson/PA765/logistic.htm.

Accessed 14 October 2010.

Griffin, J.J. \& Mahon, J.F. 1997. 'The corporate social performance and corporate financial performance debate: Twenty-five years of incomparable research', Business \& Society, 36(1):5-31.

Goleman, D. 2000. 'Leadership that gets results', Harvard Business Review, March-April:1-15.

Hanna, D. \& Newman, W.R. 2007. Integrated operations management: A supply chain perspective. $2^{\text {nd }}$ edition. Mason: South-Western.

Hanna, M.D \& Newman, W.R. 2007. Integrated operations management: A supply chain persective. $2^{\text {nd }}$ edition. Mason: South-Western.

Heskett, J.L., Jones, T.O., Loveman, G.W., Sasser, E.W. \& Schlesinger, L.A. 2008. 'Putting the service-profit chain to work', Harvard Business Review, July-August:118-129.

Heskett, J.L., Sasser, W.E. \& Schlesinger, L.A. 1997. The service profit chain: How leading companies link profit and growth to loyalty, satisfaction and value. Free Press, New York.

Hollinger, R.C. \& Langton, L. 2004. National retail security survey: Final report. University of Florida, Gainesville, FL.

Hise, R.T., Gable, M., Kelly, J.P. \& McDonald, J.B. 1983. 'Factors affecting the performance of individual chain store units: An empirical analysis', Journal of Retailing, 59(2):2239.

Howell, J.M. \& Avolio, B.J. 1993. 'Transformational leadership, transactional leadership, locus of control and support for innovation: Key predictors of consolidated business unit performance', Journal of Applied Psychology, 78(6):891-902. 
Hur, S.Y. \& Wilderom, C.P.M. 2008. Emotional intelligence, transformational leadership and performance: Evidence and challenges reviewed. Working Paper. University of Twente, The Netherlands.

Keeley, R.H. \& Roure, J.B. 1990. Management, strategy, and industry structure as influences on the success of new firms: A structural model', Management Science, 36(10): 1256-1267.

Keller, G. 2005. Statistics for management and economics. $7^{\text {th }}$ edition. Mason: Thomson South-Western.

Kirkpatrick, S.A. \& Locke, E.A. 1996. 'Direct and indirect effects of three core charismatic leadership components on performance and attitudes', Journal of Applied Psychology, 81(1):36-51.

Kruger, J.B. 2007. 'Marketing for the greater good: Community involvement marketing can work to everyone's advantage'. PMA Magazine, 1 November. [online] URL: http://www.accessmylibrary.com/article-1G1-

171400225/marketing-greater-good-community.html. Accessed 12 May 2010.

Kumar, V. \& Karande, K. 2000. 'The effect of retail store environment on retailer performance', Journal of Business Research, 49: 167-181.

Larsson, J. \& Vinberg, S. 2010. 'Leadership behaviour in successful organisations: Universal or situation dependent?', Total Quality Management, 21(3):317-334.

Moore, G. 2001. 'Corporate social and financial performance: An investigation into the U.K. supermarket industry', Journal of Business Ethics, 34: 299-315.

Moore, G. \& Robson, A. 2002. 'The U.K. supermarket industry: An analysis of corporate social and financial performance', Business Ethics: A European review, 11(1):25-39.

Nel, C. 2008. 'Sustainable leadership 2008.' Manuscript. Bellville: University of Stellenbosch Business School.

Osborne, R.L. 1995. 'The essence of entrepreneurial success', Management Decision, 33(7):4-9.

Pauler, G., Trivedi, M. \& Gauri, D.K. 2009. 'Assessing store performance models', European Journal of Operational Research, 197: 349 -359.

Payne, A., Holt, S. \& Frow, P. 2001. Relationship value management: Exploring the integration of employee, customer and shareholder value and enterprise performance models', Journal of Marketing Management, 17: 785-817.

Polat, S. 2008. 'General leadership theories and leadership in a cross-cultural context', International Strategic ResearchForum (ISREF) Perspective, 1(3):2-27.
Raman, A., DeHoratius, N. \& Ton, Z. 2001. 'Execution: The missing link in retail operations', California Management Review, 43(3):136-152.

Reinartz, W.J. \& Kumar, V. 1999. 'Store-, market-, and consumer-characteristics: The drivers of store performance', Marketing Letter, 10(1):5-22.

Reuber, A.R., Dyke, L.S. \& Fischer, E.M. 1990. Experientially acquired knowledge and entrepreneurial venture success. Toronto: University of Toronto, Faculty of Management.

Salmon, W.J. 1989. 'Retailing in the age of execution', Journal of Retailing, 65(3):368-378.

Saunders, M., Lewis, P. \& Thornhill, A. 2007. Research methods for business students. $4^{\text {th }}$ edition. Essex: Prentice Hall.

Shaffer, A. 2002. The persistence of LA's grocery gap: The need for a new food policy and approach to market development. Centre for Food and Justice, STG Angeles, May.

Silvestro, R. \& Cross, S. 2000. 'Applying the service profit chain in a retail environment: Challenging the 'satisfaction mirror', International Journal of Service Industry Management, 11(3):244-268.

Stanley, J. 2002. Just about everything a retail manager needs to know in South Africa. Cape Town: Zebra Press.

Stodnick, T.M. 2005. Driving retail store performance: A service profit chain perspective. Published $\mathrm{PhD}$ Thesis. Ohio: The Ohio State University.

Stuart, R.W. \& Abetti, P.A. 1990. 'Impact of entrepreneurial and management experience on early performance', Journal of Business Venturing, 5:151-162.

Van Eeden, R., Cilliers, F. \& Van Deventer, V. 2008. 'Leadership styles and associated personality traits: Support for the conceptualisation of transactional and transformational leadership', South African Journal of Psychology, 38(2):253-267.

Vecchio, R.P. 2003. 'Entrepreneurship and leadership: common trends and common threads', Human Resource Management Review, 13:303-327.

Wellman, D. 2007. 'Bagging big success', Retail Merchandiser, April-May:25. 